\title{
PERAN KOMUNITAS KRISTEN SEBAGAI JEMBATAN KASIH DI TENGAH PENDERITAAN BANGSA INDONESIA
}

\author{
Mathias Jebaru Adon \\ Sekolah Tinggi Filsafat Teologi Widya Sasana, Malang \\ mathiasjebaruadon@gmail.com
}

Diterima tanggal: 22 Juni 2021

Dipublikasikan tanggal: 30 Juni 2021

\begin{abstract}
ABSTRAK
Penelitian ini memiliki tujuan mengurai realitas penderitaan yang tengah menghantam dunia akibat Pandemi Covid-19 dari sudut pandang spiritualitas Kristen. Di Indonesia kondisi darurat ini diperparah oleh radikalisme agama dan berbagai macam peristiwa bencana alam. Dalam situasi ini, eksistensi manusia seolah-olah berada pada batas perziarahan. Karena itu kehadiran sesama, secara khusus orang Kristen sangat diharapkan untuk menjadi jembatan kasih Allah di tengah penderitaan sesama. Orang Kristen dapat memulainya dengan hidup dalam kasih persaudaraan di dalam komunitas. Sebab di dalam komunitas, orang Kristen dapat lebih peka mendengar penderitaan orang lain. Dengan kata lain dengan hidup dalam komunitas, orang Kristen dapat membantu mereka yang terdampak untuk keluar dari jebakan kengerian penderitaan. Oleh karena itu, kebersatuan dalam komunitas memungkinkan orang Kristen dapat menyembuhkan yang luka dan membawa orang mati kepada kehidupan. Kebaruan tulisan ini terletak pada peran komunitas Kristen sebagai wadah dan sarana bagi orang Kristen untuk mewujudkan kasih Allah di tengah penderitaan Bangsa Indonesia. Sebab tanpa kebersamaan dalam komunitas, orang Kristen akan kehilangan identitasnya, dan kasih akan menjadi ranting yang patah. Untuk menguraikan tesis tersebut, penelitian ini menggunakan pendekatan fenomenologi yang kebenarannya tidak difondasikan pada prinsip-prinsip deduktif, melainkan pada pengalaman konkret manusia.
\end{abstract}

Kata-kata Kunci: Penderitaan, Belas Kasih, Teologi dan Komunitas Kristen.

\section{ABSTRACT}

This research has the aim of unraveling the reality of suffering that is hitting the world due to the Covid-19 Pandemic from the point of view of Christian spirituality. In Indonesia, this emergency is exacerbated by religious radicalism and various natural disasters. In this situation, human existence seems to be at the limit of pilgrimage. Therefore, the presence of fellow Christians, especially Christians, is expected to be a bridge of God's love amid the suffering of others. Christians can start by living in brotherly love in the community. Because in the Christian community people are more sensitive to hear the suffering of others. In other words, by living in a community, Christians can help those affected out of the trap of the horrors of suffering. Therefore, Unity in community enables Christians to heal the wounded and bring the dead to life. The novelty of this paper lies in the role of the Christian community as a forum and means for Christians to manifest God's love in the suffering of the Indonesian nation. Because without togetherness in community, Christians will lose their identity, and love will become a broken branch. To describe this thesis, this research uses a phenomenological approach whose truth is not based on deductive principles, but concrete human experiences. 
Keywords: Suffering, Compassion, Theology and Christian Community.

\section{PENDAHULUAN}

Saat ini dunia sedang berada dalam krisis yang paling menakutkan yang belum pernah dialami selama 50 tahun terakhir. Wabah pandemi Covid-19 yang menyerang dunia pada akhir tahun 2019 telah meluluhlantakkan semua sistem. Pertumbuhan ekonomi di beberapa negara mengalami kontraksi yang begitu dalam, misalnya China dengan pertumbuhan minus 6,8 persen terburuk dalam sejarah perekonomian China. Di Eropa, Perancis dan Spanyol minus 4,1 persen (Hendranata, 2020). Di ASEAN, Singapura yang sangat terekspos dengan perdangangan internasional minus 2,2 persen. Di Thailand pada kuartal I tahun 2020 minus 1,8 persen dan pada kuartal II menjadi 10 persen, sedangkan Malaysia hanya berada pada kisaran 0,7 persen pada kuartal I tahun 2020, sementara Filiphina turun menjadi 0,2 persen ("Negara ASEAN Yang Rentan Terkena Resesi Seperti Singapura,” 2020). Menurunnya laju perekonomian di negaranegara ini disebabkan karena sektor pariwisata dan perdagangan yang menjadi tumpuan perekonomian negara tersebut mengalami tantangan hebat di masa pandemi Covid-19.

Di Indonesia hasil survei LIPI yang dirilis awal Juni tahun 2020 yang lalu memprediksi jumlah pengangguran dalam kurun waktu tiga bulan di 34 provinsi mencapai 25 juta orang. Akibatnya pertumbuhan ekonomi secara makro di tahun 2020 diperkirakan hanya 2,3 persen. Bahkan skenario terberat hanya sebesar 0,4 persen (Farhan, 2020). Bila tidak ada perubahan, pertumbuhan ekonomi Indonesia diperkirakan akan terus minus. Dengan skenario tersebut, kemiskinan bisa bertambah menjadi 4,86 juta jiwa dan pengangguran bertambah 5,23 juta orang (Farhan, 2020). Situasi ini diperparah lagi dengan maraknya politik identitas, intoleransi dan radikalisme agama yang terjadi di berbagai tempat di tanah air Hasil survei The Pew Research Center tahun 2017 sebagaimana yang dikutip oleh Novalina menunjukkan sebesar 74\% masyarakat Indonesia menanggap ISIS sebagai ancaman terbesar bagi disintegrasi bangsa dan jika dibiarkan terus menerus akan menyuburkan sikap intoleransi (Novalina, 2020). Perkembangan dan kemajuan ilmu pengetahuan dan teknologi yang begitu pesat dan mengglobal turut memicu meningkatnya isu-isu radikalisme dan intoleransi (Peter, 2020). Hal ini ditandai dengan meningkatnya ujaran kebencian, intoleransi dan radikalisme agama yang marak terjadi lewat media sosial (Qodir, 2018). 
Di samping itu memasuki tahun 2021, Indonesia menghadapi beragam bencana alam seperti banjir, longsor, gempa bumi dan erupsi gunung berapi. Menurut data Badan Nasional Penanggulangan Bencana (BNPB) sebanyak 763 bencana alam terjadi di Indonesia sepanjang triwulan pertama 2021 (Andryanto, 2021). Hal ini terjadi karena perubahan iklim global, seperti badai Siklon Tropis yang menyebabkan banjir Bandang di Nusa Tenggara Timur (NTT) 4 April 2021 lalu yang disebabkan oleh semakin naiknya suhu permukaan laut di Samudera Hindia.

Dalam kondisi ini eksistensi manusia menjadi tidak sejelas gambaran pada waktu normal. Absurditas, kecemasan dan ketakutan bercampur dengan kepasrahan. Sebab tidak dapat dipungkiri penderitaan, entah itu akibat bencana alam, kemalangan ataupun kejahatan tidak hanya mengalami kerugian harta benda, kerusakan lingkungan dan korban jiwa tetapi menimbulkan pengalaman penderitaan yang mendalam. Di masa pandemi Covid-19 pengalaman penderitaan paling terasa dialami oleh mereka yang rentan secara khusus anak-anak dan perempuan. Terjadi peningkatan yang cukup signifikan kekerasan terhadap anak-anak dan perempuan selama masa pandemi. Komnas Perempuan mencatat sebanyak 1.299 kasus terjadi selama periode Maret-Mei 2020 di Indonesia (Nixon, Sabdono, and Novalina, 2021). Hal ini tentu membawa penderitaan yang tidak kecil bagi mereka yang paling terdampak. Namun penderitaan bukanlah tuan atas hidupnya sebab dalam penderitaan manusia tetap memiliki harapan dan menemukan bantuan serta pertolongan dibalik beratnya realitas penderitaan (Rantesalu, 2020).

Heidegger menggambarkan pengalaman penderitaan manusia sebagai momen 'sudah' dan 'belum'. 'Sudah' karena eksistensi manusia sedang mengalami kerapuhan absolute; 'Belum' karena dirinya masih berada dalam pergulatan memperjuangkan dan mempertahankan eksistensinya (Riyanto, 2013). Karena itu tidak heran jika, penderitaan membuat manusia muak dengan hidup. Bagi orang beriman penderitaan menjadi problem besar karena pada hakikatnya agama-agama mengajarkan Allah sebagai Dia Yang Maha Baik. Dengan demikian, problem penderitaan juga menjadi persoalan dalam teologi Kristen karena menyasar pertanyaan mendasar tentang eksistensi Allah. Allah yang biasanya digambarkan sebagai Dia Yang 'Mahasegala'; Mahabaik, Mahabijaksana dan Mahakuasa sangat kontras dengan realitas penderitaan (Pasaribu, 2013). Dengan kata lain, penderitaan menjadi problem dalam memercayai eksistensi Allah, karena kita 
tidak dapat menyangkal adanya realitas kekerasan dan penderitaan dalam dunia. Berdasarkan hal tersebut, tulisan ini mencoba mendamaikan persoalan tersebut dengan pertama-tama memahami realitas penderitaan sebagai bagian dari realitas hidup manusia. Penderitaan sesungguhnya momen misteri karena di dalamnya tersembul misteri ke-Ilahian sebab penderitaan tidak menghentikan eksistensi manusia. Dalam penderitaan manusia mengenal temporalitas atau kesementaraan hidup.

Bila manusia mengalami kegembiraan, kemujuran semuanya hanya sementara. Demikian juga bila ia mengalami penderitaan, penderitaan itu tidak abadi; sakit itu tidak selamanya. Kesementaraan pengalaman ini, mengingatkan manusia untuk mengolah hidupnya sebaik mungkin. Tetapi untuk sampai kepada pemaknaan mendalam tersebut, diperlukan proses dan refleksi yang baik. Karena itu, bagian kedua tulisan ini akan mengurai pentingnya kehadiran sesama sebagai duta kasih Allah. Sebab pada dasarnya manusia tidak dapat dan tidak pernah hidup sendiri, ia selalu memengaruhi dan dipengaruhi orang lain. Karena itu kehadiran sesama sebagai tangan yang mau menyentuh, lengan yang mau merangkul, dan telinga yang mau mendengar dapat membantunya melintasi penderitaan dengan tidak gentar, takut dan cemas. Namun kita tidak dapat melakukannya sendiri-sendiri sebagai individu tetapi bersama-sama dalam komunitas yang dilandasi kasih persaudaraan

Karena itu kebaruan tulisan ini pertama-tama terletak pada peran komunitas Kristen sebagai wadah dan sarana kasih Allah di tengah penderitaan dunia. Sebab semangat kasih dalam hidup komunitas dapat membuka perspektif baru bagi orang Kristen dalam memahami realitas penderitaan. Dalam perspektif Kristen penderitaan bukanlah kutukan atau bencana tetapi pengalaman gentir yang menguji iman. Karena itu, wawasan dan perspektif baru ini akan mengugah hati manusia secara khusus orang Kristen untuk menjumpai sesama yang sedang menderita khususnya para korban bencana alam, korban terorisme dan radikalisme agama, serta mereka yang paling terdampak akibat pandemi Covid-19. Kedua, melalui perspektif ini orang Kristen karena imannya diundang untuk terlibat secara aktif dengan penderitaan sesama melalui tindakan kasih. Dengan cara ini orang Kristen dapat menjadi duta belas kasih Allah di tengah penderitaan bangsa Indonesia. Namun orang Kristen dituntut untuk tindak melakukannya sendiri-sendiri sebagai individu-individu tetapi dalam kebersamaan. Sebab kebersamaan lebih kuat dari bagian-bagian dan lebih kuat lagi dari individu- 
individu. Kesatuan diungkapkan pertama-tama dalam hidup bersama dalam komunitas yang dilandasi kasih. Dalam komunitas ini, orang Kristen dapat belajar mendengarkan dan merasakan penderitaan sesama, karena dengan belajar hidup berkomunitas orang Kristen dapat menjadi jembatan kasih Allah di tengah dunia yang kadang-kadang gelap karena keegoisan dan sikap apatisme manusia.

Penelitian tentang peran komunitas Kristen di tengah penderitaan bangsa Indonesia telah banyak dilakukan dengan penekanan yang berbeda-beda. Penelitian yang dilakukan Rantesalu (2020) membahas penderitaan selama Covid-19 dari sudut padang teologi Injili. Penelitian ini menemukan penderitaan dan bencana merupakan kehendak dan kedaulatan Allah. Penelitian yang sama dilakukan oleh Nixon, Sabdono dan Novalina (2021) yang melihat penderitaan yang tidak kasat mata yang dialami perempuan dan anak-anak Indonesia akibat kekerasan selama masa pandemi Covid-19. Dalam nada yang sama Tefbana dan Rantung (2020) membahas perspektif pendidikan agama Kristen terhadap teologi kebencanaan dan peran gereja dalam mendidik umatnya. Penelitian tersebut menemukan bencana merupakan bagian yang tidak terpisahkan dari kehidupan manusia. Kitab Suci sendiri telah menjelaskan berbagai bencana terjadi dalam kehidupan umat pilihan Allah, sebagai bagian dari kehadiran Allah dalam mendidik dan menghukum umat-Nya (Tefbana and Rantung, 2020).

Berdasarkan hal tersebut penelitian ini bertujuan meneliti peran komunitas Kristen sebagai jembatan kasih Allah di tengah penderitaan dunia dari sudut padang teologi katolik dan filsafat. Dalam teologi Katolik penderitaan bukanlah hukuman dari Allah tetapi ujian bagi iman. Dalam iman manusia dapat melihat rencana dan rahmat Allah dibalik getirnya penderitaan, sebab Allah sendiri ikut menderita dalam diri Kristus. Penyelamatan manusia terjadi melalui peristiwa salib. Pandangan dunia filsafat sangat baik menjelaskan hal ini yang memandang penderitaan bukan sebagai hukuman dari Allah tetapi proses pendewasaan manusia. Dalam penderitaan manusia merasakan betapa indah dan berharganya kebahagiaan. Kebahagiaan adalah sesuatu yang mesti diperjuangkan oleh semua orang (Kasiyun, 2013). Kebahagiaan paling dirasakan manusia ketika mengalami kasih dan cinta. Namun hakikat cinta sifatnya altruis dan selalu menyangkut dengan yang lain. Begitu berharganya kasih sehingga dalam teologi Katolik tugas menjadi duta kasih adalah panggilan dasar orang Kristen sebagai barometer kekatolikan. Berkaitan dengan panggilan tersebut orang Kristen diajak untuk 
mewujudkan kasih tersebut tidak sendiri-sendiri sebagai individu-individu tetapi bersama-sama dalam komunitas kasih persaudaraan. Sebab dalam komunitas hati dan perasaan selalu peka dengan penderitaan dan kesulitan sesama (Wilhelmus, 2013).

\section{METODE}

Studi penelitian ini menggunakan metode penelitian kepustakaan dalam sudut pandang fenomenologi. Edmund Husserl sebagai pencetus filsafat fenomenologi menyebut metode fenomeologi sebagai science yang dapat mengubah dunia karena menawarkan implikasi-implikasi prosedural tentang bagaimana kebenaran diraih, bagaimana realitas dipahami sebagaimana adanya dan bagaimana cara hidup manusia di dekati (Husserl, 1982). Alfred Schutz bahkan menyebut fenomenologi sebagai metodologi yang meminati pengalaman manusia (Schutz, 2011). Maksudnya, dunia pengalaman manusia tidaklah dimaksudkan subyektif sebagai lawan dari obyektif (ilmiah) sebab pengalaman manusia adalah sesuatu yang nyata dalam hidup manusia meski hal tersebut dialami oleh satu atau dua orang saja. Salah satu kejadian yang dapat dijadikan contoh adalah peristiwa bom bunuh diri di Makasar yang terjadi 28 Maret 2021 telah menghadirkan kengerian yang nyata tidaklah dipandang sebagai tidak obyektif hanya karena dialami beberapa orang saja (Ryiandi and Ridwan, 2021).

Dengan kata lain dalam fenomenologi, sesuatu itu dikatakan obyektif bukan karena kekurangan sampel tetapi karena berasal dari pengalaman nyata manusia. Inilah kekhasan dalam penelitian fenomenologi yang menaruh minat terutama dunia pengalaman manusia. Sebab dunia pengalaman manusia adalah dunia sejarah manusia (historisitas). Berkaitan dengan penelitian fenomenologi Armada Riyanto (2018) menjelaskan bahwa manusia dengan pengalamannya adalah komponen tunggal dari apa yang disebut sejarah. Karena itu menurut Armada Riyanto, nilai-nilai kehidupan dan nilai-nilai yang terkait dengan edukasi atau yang sejenisnya tidak datang dari langit atau dari pedoman penguasa siapa pun melainkan dari manusia dengan segala pengalamannya (Riyanto, 2018)

Berdasarkan hal tersebut gagasan pokok penelitian dikaji dan dianalisis dari sudut pandang filsafat dan teologi. Sumber data penelitian dibagi menjadi dua bagian yakni sumber data primer dan sumber data sekunder. Sumber data primer diperoleh dengan melakukan studi kepustakaan atas Kitab Suci dan Ajaran Magisterium Gereja. 
Sumber data sekunder dilakukan dengan meneliti pandangan para filosof yang berbicara tentang penderitaan. Dengan demikian, fokus penelitian ini dijalankan melalui pendalaman sumber-sumber kepustakaan atas ajaran-ajaran Gereja Katolik seperti; dokumen-dokumen Gereja, Kitab Suci dan Ajaran Magisterium serta pemikiran para filsuf yang membahas pokok persoalan dalam penelitian. Sumber data sekunder diperoleh dari surat kabar, jurnal-jurnal ilmiah majalah dan buku-buku yang membicarakan tentang penderitaan yang menjadi fokus utama dalam penelitian ini. Kedua sumber data ini didalami dan dianalisis dalam sudut pandang fenomenologi. Hasil studi kepustakaan ini dijadikan landasan dalam mengkaji fenomena realitas penderitaan yang sedang dialami bangsa Indonesia dan bagaimana orang Kristen dipanggil untuk menjadi duta kasih Allah. Namun disadari kompleksnya realitas penderitaan sehingga orang Kristen tidak dapat melakukan sendiri-sendiri sebagai Individu tetapi dalam kesatuan dengan komunitas. Oleh karena itu studi penelitian ini pada peran komunitas Kristen sebagai jembatan kasih Allah di tengah penderitaan Bangsa Indonesia.

\section{HASIL DAN PEMBAHASAN}

\section{Pemaknaan Terhadap Penderitaan Manusia}

Penderitaan adalah realitas yang harus diterima manusia sebagai fakta hidup. Manusia adalah dia yang bergulat dengan pengalaman duka dan kecemasan, kegembiraan dan harapan, tawa dan tangis. Kehadiran penderitaan dalam hidup manusia seolah-olah menuntut manusia untuk menentukan sikap, menerima atau menolak. Menolak berarti menjadikan penderitaan sebagai sesuatu yang absurd, hampa, dan tidak berarti. Sebab penderitaan pada dasarnya adalah fakta yang menjadi bagian dalam hidup manusia bahkan penderitaan sudah menyentuh seluruh aspek kehidupan manusia sejak lahir (Daliman, 2018). Aristoteles menggambarkan hal itu dengan sangat baik, jika penderitaan datang menghampiri seseorang dan yang bersangkutan menolaknya kita tentu menaruh kasihan. Sebaliknya ketika seseorang menerimanya dengan tabah, kita akan menaruh rasa hormat dan kagum (Riyanto, 2013). Dengan kata lain penderitaan bagian yang nyata dalam peziarahan hidup manusia dan terus bergulir dalam pengalaman sehari-hari manusia. 
Zaman ini saat hidup manusia dipenuhi dengan metode dan teknik yang dirancang untuk mempengaruhi tingkah laku dan mengubah hidup manusia perasaan terancam dan rasa takut secara eksistensial terutama yang berkaitan dengan penderitaan semakin meningkat (Paus Yohanes Paulus II, 1980). Rumah sakit dan kamar mayat sering kali menjadi tempat untuk menyembunyikan yang sakit dan yang mati. Penderitaan tidak menarik untuk tidak mengatakan memuakkan dan menjijikkan. Semua ini menjadi latar belakang yang menunjukkan bagaimana jati diri manusia menyerah pada sekularisasi. Padahal penderitaan adalah realitas eksistensial yang menyentuh kodrat dan eksistensi manusia (Pandor, 2014). Oleh sebab itu meski penderitaan membawa kekecewaan dan putus asa namun manusia dengan akal budinya dapat menemukan sesuatu yang positif dalam penderitaan sehingga tidak sampai menyeretnya kepada sesuatu sikap ekstrim yang fatal.

Secara eksistensial manusia adalah homo patiens, dia yang bergulat dengan pengalaman duka dan kecemasan, tawa dan tangis dalam keseharian hidupnya. Sebab dalam kenyataannya pengalaman penderitaan tidak akan absen dari setiap manusia, apapun dan di manapun ia berada. Alkitab memberikan jawaban yang cukup memuaskan mengenai penderitaan yang menyatakan bahwa, penderitaan tidak hanya dialami oleh orang fasik, melainkan juga oleh orang-orang saleh. Kisah penderitaan Ayub mengafirmasi hal ini bahwa penyertaan Allah bagi orang yang percaya tidak berarti meniadakan pergumulan penderitaan melainkan karena iman memampukan dia untuk tetap percaya kepada-Nya sehingga kuat dan bertahan sampai akhirnya menang atas penderitaan yang dihadapi (Nicolas, 2021). Dengan kata lain, penderitaan merupakan bagian dari eksistensi manusia yang tidak dapat dihindari atau dihentikan oleh manusia. Manusia hanya mampu untuk mengurangi rasa sakit yang diderita sedangkan realitas penderitaan tidak dapat dielakkan.

Meski demikian penderitaan bukanlah tuan atas hidup manusia karena dibalik penderitaan selalu ada harapan dan pertolongan yang meneguhkan hati untuk bangkit dan melanjutkan kehidupan (Rantesalu, 2020). Inilah kedalaman pengalaman manusia, di satu sisi manusia tidak dapat mengelak realitas penderitaan yang dialaminya tetapi di sisi lain manusia mampu menghayati hidupnya dengan menyambut penderitaan dengan keteguhan jiwa dan menyongsong akhir hidup dengan bakti. Tidaklah berlebihan jika Heidegger memaknai penderitaan yang lama dan berat sebagai momen eksistensi 
manusia berada dalam batas akhir hidupnya. Kondisi ini digambarkan Heidegger sebagai kematian, saat being manusia terhenti dengan segala pengalamannya (Riyanto, 2013). Heidegger mengerti kematian bukan saat malaikat maut datang mencabut nyawa tetapi ketika eksistensi manusia tidak mengada (being) lagi atau ketika manusia berhenti berziarah dalam perjalanannya menjadi manusia.

Armada Riyanto melukiskan pengalaman penderitaan seperti manusia berada dalam In-between eksistensinya (Riyanto, 2013) Terminologi in-between mengusung kebenaran bahwa hidup manusia itu berjalan-menjadi-mencintai. Leibniz dengan sangat indah menjelaskan penderitaan dengan mengatakan penderitaan menjadi moment yang diperlukan untuk mencapai kemajuan. Dengan ini Leibniz hendak mengatakan bahwa, saat-saat gelap hidup bukan sebagai kronos atau saat-saat kosong, tanpa makna dan memuakkan. Tetapi sebagai suatu kairos atau kesempatan yang membawa seseorang kepada perkembangan. Sebab manusia dengan kapasitas yang dimilikinya mampu melewati penderitaan (Hadirman, 2007). Descartes dalam nada yang sama pernah menulis, sesuatu itu bisa dengan alasan tertentu tampak sangat tidak sempuma bila dilihat hanya sebagai satu bagian kecil saja dari suatu realitas yang lebih besar. Demikian halnya dengan penderitaan, diperlukan untuk menampilkan lebih jelas keindahan dan kebaikan yang lebih besar (Kewuel, 2013)

Dengan perspektif seperti ini penderitaan akan berkurang makna suramnya. Karena itu, penderitaan bukan lagi peristiwa kematian karena being manusia yang terhenti tetapi proses lahirnya sejarah baru karena eksistensi manusia berlanjut menuju kepenuhannya. Kisah penderitaan yang dialami oleh Martin Luther King yang memperjuangkan pembebasan budak kulit hitam dapat dijadikan contoh bagaimana penderitaan tidak dapat menghentikan eksistensi manusia. Dalam suratnya kepada kelompok rasisme kulit putih di sel penjara Georgia, Martin menulis, 'Lemparkan kami, kami tetap mengasihi! Lemparkan Bom ke rumah kami, dan ancamlah anak-anak kami, kami tetap mengasihi!' (W., 2013). Pengalaman penderitaan Martin Luther King menyadarkan setiap orang bahwa, manusia sesungguhnya mampu menampilkan cinta yang luar biasa meski dalam penderitaan yang hebat sekalipun. Dengan kata lain penderitaan sesungguhnya mengandung nilai pedagogis yang dalam dan indah.

Dalam teologi Kristen penderitaan yang dialami manusia bukanlah suatu kutukan atau penyakit dari Allah. Penderitaan adalah pengalaman gelap dan getir yang 
menguji kesetiaan iman. Sebab setiap orang pasti akan mengalami penderitaan, meski dengan tingkat yang berbeda-beda. Tetapi penderitaan yang dialami tidak akan melampaui batas kemampuan manusia, tergantung bagaimana menanggapinya (Nicolas, 2021). Singkat kata dalam iman, seseorang dapat mengubah penderitaan menjadi anugerah yang menghasilkan buah-buah rohani jika menyatukannya dengan penderitaan Kristus. Karena itu, Gereja memandang kesengsaraan atau penderitaan sebagai godaan terbesar dalam hidup orang beriman (KGK 1500).

\section{Tantangan Memaknai Penderitaan}

Saat ini dunia tengah diwarnai oleh persaingan, oleh karenanya umat manusia dicabik-cabik oleh konflik, perang, kebencian dan penindasan demi persaingan yang sedang mereka perjuangkan. Apa yang sesungguhnya menjadi perhatian manusia adalah bagaimana mereka dapat berhasil dalam kehidupan, maju dan menjadi yang pertama. Perasaan terancam dan rasa takut secara eksistensial terutama yang berkaitan dengan penderitaan semakin meningkat. Rumah sakit dan kamar mayat seringkali menjadi tempat untuk menyembunyikan yang sakit dan yang mati. Penderitaan tidak menarik untuk tidak mengatakan memuakkan dan menjijikkan (Nouwen, Mcneill, and Morrison, 1987). Salah satu yang paling tragis pada zaman ini adalah manusia tahu tentang kemalangan dan penderitaan tetapi semakin tidak mampu menanggapinya (Paus Fransiskus, 2015). Hal ini terjadi karena media elektronik, media sosial, dan media cetak memungkin setiap orang setiap saat mengetahui apa yang terjadi di dunia ini sehingga membuat nuraninya terbiasa dengan berita tentang penderitaan.

Melalui media, kita mendengar pertikaian, pembunuhan, gempa bumi, kelaparan, penyiksaan dan berbagai bentuk penderitaan manusia yang tak terhitung jumlahnya. Rupanya warta media masa hampir menjadi litani penderitaan yang tak pernah selesai. Namun persoalannya, apakah bentuk-bentuk komunikasi yang begitu canggih dan informasi yang banyak semakin memperdalam solidaritas? Hal ini sangat disangsikan. Beberapa waktu terakhir media khususnya media sosial kerapkali disalahgunakan sehingga menyebabkan masyarakat terpolarisasi dan terfragmentasi berdasarkan identitas suku, agama, dan ras (Raharso, 2019). Dengan kata lain, kemajuan sarana-sarana komunikasi tidak menjamin solidaritas dalam masyarakat. Di samping itu, kalau penderitaan dunia ditujukan kepada orang-orang yang sudah penuh dengan 
persoalan yang muncul dari lingkungan keluarga sahabat atau kenalan mereka, bagaimana mungkin mengharapkan jawaban yang kreatif dari mereka? Justru yang kita peroleh adalah kebalikan dari sikap simpati: acuh dan marah. Pameran penderitaan yang berlebihan seringkali membuat orang bisu secara psikis. Budi manusia tidak tahan untuk selalu diingatkan akan hal-hal yang mengganggu apa yang sedang kerjakan.

Kalau membiarkan seluruh warta berita tentang penderitaan masuk ke dalam hati dan sanubari, kita akan begitu dibebani oleh absurditas kehidupan dan menjadi lumpuh. Kalaupun menyerap semuanya, kita tidak akan menyelesaikan satu pekerjaan pun. Naluri efisiensi manusia menuntut adanya sistem penyaringan mental. Dengan sistem itu manusia dapat melunakkan pengaruh berita sehari-hari. Selain itu pemberitaan tentang penderitaan manusia pada tingkat yang begitu massal tidak hanya menimbulkan orang bisu secara psikis, tetapi juga dapat menimbulkan sikap bermusuhan. Dalam kadar yang menggemparkan itulah dapat mengerti apa yang terjadi dalam kamp-kamp konsentrasi Nazi dan Chili (Riyanto, 2013).

Dalam kamp-kamp konsentrasi tersebut, semakin buruk rupa tawanan, semakin mudah pula tampaknya penyiksaan dan penganiayaan yang kejam. Oleh sebab itu tidak mengherankan kalau buku Anne Frank berperan lebih besar untuk lebih mengenal penderitaan manusia daripada film-film panjang yang mempertunjukkan wajah-wajah kelaparan, bangunan-bangunan gelap dengan cerobong asap hitam serta bertumpuktumpuk mayat kotor dan telanjang. Kita dapat mengerti Anne Frank sedangkan tumpukan mayat manusia membuat kita muak. Karena itu masalahnya bagaimana manusia zaman sekarang dapat melihat penderitaan dunia dan hatinya tergerak oleh belas kasih. Pertanyaan ini begitu mendasar dimana manusia melihat begitu banyak penderitaan tetapi sedikit sekali hatinya berbelas kasih (Nouwen, 1998).

\section{Menjadi Duta Belas Kasih Allah Di Tengah Penderitaan Dunia}

Dalam dunia yang tampak kelabu yang diwarnai oleh rasa takut yang semakin mewabah dan rasa putus asa yang menggelisahkan dapat dibayangkan dan dimengerti bahwa semakin banyak orang yang bunuh diri dan tidak sedikit yang kecanduan obat bius (Kurniawan, 2020). Dari data yang dirilis oleh WHO Global Health Estimates pada 25 Juli 2020 tercatat jumlah kematian akibat bunuh diri mendekati 800.000 per tahun atau satu orang kematian setiap 40 detik. Di Indonesia kasus bunuh diri rata-rata 9. 000 kasus per tahun (Suchaini, 2020). Dalam situasi darurat ini, perbuatan kasih hadir untuk 
menjadi terang, garam dan ragi bagi dunia. Kehadiran sesama diharapkan menjadi duta kasih yang menawarkan harapan, kepercayaan dan keberanian. Heidegger mengatakan manusia adalah "Being-In- The World” (Rouse, 2007). Dengan menyebut manusia being in the world, Heidegger pada saat yang sama mengatakan manusia, "Being-InThe Others" (Soebagiyo, 2020). Konsekuensinya, subjektivitas manusia selalu mengandaikan dengan yang lain. Oleh karena itu, ketika kita melihat seorang manusia, kita tidak bisa menjadi penonton pada eksistensinya; apa yang menjadi pertaruhannya menjadi pertaruhanku. Kalau manusia, being in the others maka nilai kebaikan dan cinta memiliki makna dan asal-usulnya dari relasi intersubjektif.

Suatu kemunduran jika manusia yang secara hakiki makhluk sosial bersikap tak acuh terhadap sesamanya. Itu berarti ia menyangkal kodratnya sebagai subjek yang sudah ditentukan untuk berada di antara subjek yang lain. Persoalannya kehidupan sosial saat ini sedang terjangkit penyakit apatisme, individualisme dan egoisme yang tinggi. Penyakit ini telah menghancurkan kesadaran manusia sebagai makhluk sosial. Dalam konteks inilah panggilan dan tugas orang Kristen untuk mewujudkan imannya dengan menjadi duta belas kasih Allah. Karena itu, Henri Nouwen sebagai seorang guru spiritual Kristen modern mengajak setiap orang secara khusus orang Kristinai untuk mengarahkan perspektifnya pada kata-kata Yesus, "Hendaklah kamu berbelas-kasih sama seperti Bapamu berbelas-kasih" (Luk 6:36) (Nouwen et al., 1987). Nouwen yakin dengan bersandar pada kata-kata Yesus ini kemanusian kita akan berkembang dalam kepenuhannya. Menurutnya perintah ini tidak menyatakan kembali hal yang sudah jelas tetapi sesuatu yang sudah diinginkan tetapi dilupakan. Suatu ide yang sejalan dengan kodrat manusiawi tetapi terabaikan.

Menurut Nouwen belas kasih Allah adalah belas kasih yang tidak diwarnai oleh persaingan. Ia mengambil bagian dalam hidup manusia, berbagi rasa dengan penderitaan dan kesulitan manusia, serta menanggung semua suka-duka hidup manusia. Solidaritas-Nya tidak berarti bahwa Dia memecahkan persoalan-persoalan manusia, memperlihatkan jalan keluar dari kebingungan atau memberikan jawaban-jawaban untuk setiap pertanyaan manusia. Allah mungkin saja melakukan itu, tetapi solidaritasnya ada dalam kenyataan bahwa Dia rela bersama manusia masuk dalam persoalan-persoalan, kebingungan dan pertanyaan manusia. Oleh karena itu di hadapan jutaan orang yang menderita kelaparan, kedinginan dan tidak mempunyai tempat tinggal 
orang Kristen tidak bisa tinggal diam. Orang Kristen diutus untuk menjadi duta-duta belas kasih Allah. Sebab Allah sendiri telah berpihak kepada mereka yang menderita dalam diri Yesus. Dalam kotbah-Nya mengenai akhir zaman Yesus berkata: "Hai kamu yang diberkati Allah terimalah kerajaan yang telah disediakan Allah kepadamu sejak dunia dijadikan. Karena segala sesuatu yang telah kamu lakukan untuk salah seorang saudaraku yang paling ini, telah kamu lakukan untuk Aku. Sebab ketika ia lapar kamu memberi dia makan, ketika ia haus kamu memberi dia minum, ketika ia seorang asing kamu memberi dia tumpangan, ketika ia telanjang kamu memberi pakaian, ketika ia sakit kamu melawatnya, ketika ia dalam penjara kamu mengunjunginya" (Bdk. Mat 25:34-40).

Inilah keberpihakan yang menuntut orang Kristen pergi ke tempat di mana ada luka, masuk ke tempat-tempat di mana ada penderitaan, ikut serta dalam keterpecahan, ketakutan, kebingungan dan kecemasan orang lain. Keberanian menghadapi situasi dalam kerendahan hati, penuh bela rasa itulah memungkinkan orang Kristen atau siapa pun dapat menjadi duta belas kasih Allah. Kalau orang Kristen memandang belas kasih dengan cara ini, menjadi jelas bahwa di dalamnya terkandung lebih dari sekedar satu keramahan atau kelembutan yang biasa. Karena itu, Bernardus dari Clairvaux mengungkapkan pengertiannya tentang kemampuan Allah untuk menderita dengan suatu ungkapan bahwa Allah tidak mampu menderita, tetapi itu tidak berarti Dia tidak mampu mengambil bagian dalam penderitaan orang lain (Nouwen, 2008). Denegan kata lain penderitaan Allah adalah cara Allah mengungkapkan kasih-Nya yang besar kepad manusia.

Agustinus mengungkapkan hal yang sama, "Bukanlah karena tidak perlu untuk kondisi-Nya melainkan karena kehendak baik-Nya untuk ikut merasakan penderitaan manusia"(Kasper, 2016). Solidaritas Allah adalah jalan menuju keyakinan mengenai kebenaran bahwa yang menjadikan diri kita paling manusiawi kalau kita melayani, mencintai dan berbagi rasa dengan sesama. Inilah jalan yang mendatangkan penyembuhan dan perdamaian.

Nouwen memberikan contoh bagaimana solidaritas Allah dapat dipahami, bahwa sering kali kita berkata dengan nada yang sinis "Engkau tidak tahu apa yang kau katakan sebab engkau tidak turun ke jalan, ikut serta dalam pemogokan, sebab engkau tidak pernah lapar, tidak pernah kedinginan atau merasakan pengucilan”(Nouwen et al., 
1987). Saat menyatakan ini, kita mengungkapkan keyakinan yang mendalam bahwa kita bersedia untuk mendengarkan kata-kata penghiburan kalau kata-kata itu muncul dari solidaritas dengan sesama. Maka kabar baik yang sesungguhnya bahwa Allah bukanlah Allah yang jauh, yang harus ditakuti dan dihindari, atau Allah pemalas tetapi Allah yang tergerak oleh penderitaan. Di sini kita melihat arti belas kasih Allah bahwa, belas kasih bukanlah suatu pandangan ke bawah dari orang-orang yang mempunyai hak-hak istimewa kepada mereka yang papa; bukan suatu uluran tangan dari atas kepada mereka yang kurang beruntung; bukan suatu sikap simpati atau kasihan kepada mereka yang gagal dalam usaha bergerak naik. Sebaliknya belas kasih berarti pergi secara langsung kepada orang-orang dan tempat-tempat di mana penderitaan yang paling kejam dirasakan.

\section{Komunitas Kristen Sebagai Sarana Menumbuhkan Kasih Allah}

Masalah pokok pada bagian ini adalah bagaimana cara membudayakan kasih di tengah penderitaan dunia yang dilanda egoisme dan apatisme sehingga orang lain dapat mengalami kehadiran orang Kristen dan berkata, "Lihat bagaimana mereka saling mengasihi, bagaimana mereka dapat melayani sesama dan bagaimana mereka berdoa kepada Tuhan mereka"(Nouwen, 1998). Gereja Perdana menunjukkan secara mengagumkan bagaimana budaya kerahiman diwujudkan. Kisah Para Rasul menceritakan bagaimana Perjamuan Tuhan dihubungkan dengan perjamuan agape (kasih), dan melayani meja sudah ada sejak dalam komunitas awal di Yerusalem (Kis. 6:1-4). Pada zaman Bapa Gereja sekitar abad 2 dan abad ke-3, Tertullianus melaporkan bahwa cara kaum Kristen memperhatikan kaum fakir miskin, sangat mengagumkan bagi kaum kafir. Sejarah santo-santa membuktikan bagaimana belas kasih Allah mengubah hati seseorang. Sebutlah Lewi si pemungut cukai menjadi Matius penulis Injil, Saulus menjadi Paulus dan Agustinus yang bertobat. Karena itu, komunitas Kristen menjadi harapan dan sumber kepercayaan serta memberi keberanian kepada sesama. Inilah yang oleh Agustinus menjadi tujuan persekutuan hidup Kristen yakni menjadi tanda yang nyata akan hidup sehati sejiwa menuju Allah (Utomo, 2018). Di sini setiap orang Kristen diundang untuk mewujudkan kasihnya kepada Allah dengan menghargai sesama sebagai Bait Allah. Agustinus yakin bahwa keberadaan sesama manusia atau teman berperan penting dalam perjalanan manusia menuju Allah. Sebab tak seorang pun dapat mencapai Allah hanya dengan akal budinya saja. Solidaritas, partisipasi atau 
kebersamaan merupakan konsep kunci dalam perjalanan hidup setiap orang yang sedang berjalan masuk ke hadirat Allah.

Penegasan ini secara mendasar memberi kesaksian bahwa kehadiran Allah yang berbelas-kasih di dalam dunia terjadi dengan cara manusia hidup bersama dan berkerja sama. Hidup yang berbelas-kasih dengan demikian adalah hidup dalam komunitas, dimana persahabatan dengan Kristus mewujud dalam persaudaraan baru. Dalam komunitas yang baru ini manusia menjadi umat baru dengan pikiran, perasaan dan harapan yang baru. Kalau demikian belas kasih tidak pernah dapat dipisahkan dari komunitas (Kelelufna, 2017). Belas kasih menyatakan diri secara utuh dalam komunitas. Sebab dalam komunitas manusia menemukan satu sama lain sebagai kawan perjalanan dalam lorong yang sama ketika dia menjadi terbuka dan siap menerima penderitaan dunia dan memberikan tanggapan dengan sepenuh hati. Persatuan itu menjadi sedemikian rupa sehingga setiap orang berkembang dalam kemerdekaan batinnya. Oleh sebab itu dalam komunitas Kristen mata dan telinga kita akan selalu terbuka untuk mendengar segala sesuatu yang terjadi sehingga kita dapat mengerti tentang kelaparan, penindasan dan penyiksaan.

Menanggapi panggilan ini orang Kristen dapat melakukannya dengan tindakan yang konkrit yang dimulai dari lingkungan di sekitarnya lalu meluas ke tingkat dunia. Namun orang Kristen tidak dianjurkan untuk melakukannya sendiri-sendiri sebagai individu tetapi dalam kerjasama satu sama lain, seperti yang dilakukan oleh kelompok awam misioner BKK yang menaruh perhatian pada pendidikan daerah terpencil secara khusus para pengungsi korban pergolakan Timor Leste tahun 1999 di Atambua-NTT (Matarona, 2019). Demikian halnya semangat yang sama yang dilakukan oleh Thomas Huggett beserta kawan-kawannya di Chicago AS, yang menghabiskan waktu pensiunnya untuk merawat orang-orang yang rentan, khususnya di masa pandemi Covid-19 (Hanggu, 2020). Dalam konteks budaya Indonesia semangat ini dapat diwujudkan dengan memanfaatkan kearifan lokal setempat.

Membangun semangat kebersamaan dan kesatuan dalam komunitas Kristen di Indonesia sesungguhnya bukanlah sesuatu yang sulit sebab semangat ini sesuai dengan citra budaya Indonesia yang sangat menjunjung tinggi semangat gotong royong. Karena itu, untuk membangun komunitas Kristen di Indonesia mesti memanfaatkan kearifan lokal setempat dimana Gereja itu bertumbuh. Salah satu yang dapat dijadikan contoh 
misalnya membangun komunitas Kristen di Kabupate Manggarai dengan menggunakan konsep lonto leok dalam budaya Manggarai, Flores-NTT. Dalam budaya Manggarai lonto leok berarti musyawarah bersama satu kampung (beo) (Mahur and Bustan, 2019). Kearifan ini sesuai dengan spiritualitas komunitas Kristen yang menempatkan persaudaraan sejati sebagai landasan hidup bersama.

Dengan cara seperti ini, komunitas Kristen dapat menjadi jembatan kasih yang sungguh menyalurkan rahmat Allah di tengah penderitaan bangsa Indonesia. Demikian halnya dengan Gereja yang tumbuh di tanah Papua, Dayak atau Batak dapat memanfaatkan kearifan budaya setempat untuk membangun komunitas Kristen yang sejati. Salah satunya yang tampak dalam mitigasi bencana pandemi Covid-19 yang menggunakan konsep Jogo Tonggo di Jawa Tengah. Jogo Tonggo berarti saling menjaga tetangga (Arditama and Lestari, 2020). Dalam kearifan lokal ini terbentuk kesadaran bersama dan ketaatan masyarakat terhadap himbauan pemerintah, serta menumbuh-kembangkan solidaritas sosial di antara sesama warga masyarakat khususnya umat Kristen yang membantu membuat dan membelikan masker bagi masyarakat (Yoni, 2020).

\section{KESIMPULAN}

Penderitaan adalah fakta tak terbantahkan dalam hidup manusia. Di hadapan penderitaan, eksistensi manusia terhentak. Kebermaknaan dan kebebasan dirinya berjalan pelan, macet dan cacat. Secara khusus bangsa Indonesia, saat menghadapi masa pandemi Covid-19, membuat penderitaan semakin berat dirasakan, sebab tidak hanya pandemi Covid-19 yang dihadapi, tetapi juga berbagai bencana alam harus disikapi. Dalam kondisi ini, Bangsa Indonesia diperhadapkan pada kenyataan menerima atau menolaknya. Bagi setiap manusia, tidak jarang manusia mengelak, akibatnya ia terjebak dalam pengalaman negatif yang merusak eksistensinya sebagai makhluk yang rasional dan spiritual. Meski demikian tidak sedikit orang yang mampu keluar dari penjara penderitaan. Mengingat hal itu, manusia tidak dapat berjalan sendiri menghadapi getirnya penderitaan. Manusia membutuhkan eksistensi di luar dirinya yang menjadi sahabat dalam melintasi penderitaan sekaligus memberi kekuatan baginya untuk keluar dari jerat penderitaan. Dalam iman Kristen eksistensi tersebut tidak lain adalah Allah sendiri yang telah menderita dalam diri Kristus. 
Jean-Luc Marion (1946-1970) menulis Die sans l'ětre (Allah tanpa Mengada). Menurutnya iman Kristen adalah iman kepada Allah yang mati, tetapi justru karena demikian orang Kristen mampu melintasi penderitaan. Karena itu orang Kristen dipanggil untuk mewartakan pengharapan dengan menjadi duta kasih Allah di tengah penderitaan Bangsa Indonesia. Namun dalam melaksanakan amanat tersebut orang Kristen diajak untuk tidak melakukan sendiri-sendiri sebagai individu tetapi dalam kebersamaan dalam komunitas. Di dalam komunitas, orang Kristen dapat belajar dan peka dengan penderitaan sesama.

Sebab dengan hidup dalam komunitas, orang Kristen akan menjadi terbuka dan siap menerima penderitaan dunia ini dan memberikan tanggapan dengan sepenuh hati. Sebab di mana orang berkumpul dalam nama Yesus, disitu Kristus hadir sebagai Tuhan yang berbelas-kasih (bdk. Mat. 18:20). Kehadiran dan keterlibatan Allah ini menegaskan panggilan orang Kristen bahwa di hadapan jutaan orang yang menderita kelaparan, kedinginan, ditinggalkan dan kesepian, orang Kristen tidak bisa tinggal diam. Orang Kristen diutus untuk menjadi duta belas kasih Allah, karena Allah sendiri telah berpihak kepada mereka yang menderita dalam diri Yesus. Sebab dengan cara demikian, orang Kristen dapat menyembuhkan orang sakit dan membawa orang mati kepada kehidupan.

\section{DAFTAR PUSTAKA}

Andryanto, S. D. (2021). Bnpb : Total 763 Bencana Alam Di Indonesia Sepanjang Triwulan Pertama 2021. Retrieved April 7, 2021, From Tempo.Co Website: Www.Tempo.Co

Arditama, E., And Lestari, P. (2020). Jogo Tonggo : Membangkitkan Kesadaran Dan

Ketaatan Warga Berbasis Kearifan Lokal Pada Masa Pandemi Covid-19 Di Jawa

Tengah. Jurnal Pendidikan Undiksha, 8(2), 157-167. Retrieved From

Https://Ejournal.Undiksha.Ac.Id/Index.Php/Jjpp

Daliman, M. (2018). Ournal Bijak Vol. 1, No. 2. Mei 2018 Ssn 2599-011x. Jurnal

Bijak, 1(2), 20-28.

Farhan, Y. (2020, April 16). Anggaran Darurat Covid-19. Kompas.

Hadirman, F. B. (2007). Filsafat Modern: Dari Machiavelli Sampai Nietzsche. Jakarta:

Gramedia.

Hanggu, F. P. (2020). Pejuang Martabat Tuna Wisma. Hidup Katolik. 
Hendranata, A. (2020). Stimulus Dan Koordinasi. Kompas, P. 7. Retrieved From Https://Www.Kompas.Id/Baca/Opini/2020/06/03/Stimulus-Dan-Koordinasi/ Husserl, E. (1982). Ideas Pertaining To A Pure Phenomenology And To A

Phenomenologycal Philosophy (First Book; F. Kersten, Ed.). The Hague: Nijhoff. Kasiyun, S. (2013). Sidharta Karya Hermann Hesse Dan Di Tepi Sungai Piedra Aku Duduk Dan Menangis Karya Paulo Coelho Dalam Filsafat Eksistensialisme Dan Pencarian Pencerahan. Paramasastra : Jurnal Ilmiah Bahasa Sastra Dan Pembelajarannya, 1(1), 83-91.

Kasper, W. (2016). Belas Kasih Allah: Dasar Kitab Suci Dan Kunci Hidup Kristen (Karmelindo, Ed.). Malang.

Kelelufna, J. H. (2017). Allah Segala Maha Di Tengah Fenomena Kekerasan Dan Penderitaan Orang Saleh. Kenosis: Jurnal Kajian Teologi, 3(2), 109-133. Kewuel, H. K. (2013). Memandang Tuhan Dari Balik Pengalaman Kejahatan, Penderitaan, Dan Kematian. Jpak Jurnal Pendidikan Agama Katolik, 53(9), 16891699.

Kurniawan, D. (2020). Redakan Stres Saat Pandemi Agar Tak Terjerumus Kecanduan Narkoba. Retrieved From Jawa Pos Website:

Https://Www.Jawapos.Com/Kesehatan/26/06/2020/Redakan-Stres-Saat-PandemiAgar-Tak-Terjerumus-Kecanduan-Narkoba/

Mahur, A., And Bustan, F. (2019). Konseptualisasi Masyarakat Manggarai Tentang Budaya Lonto Leok Sebagai Piranti Hukum Adat Responsif-Sosiologik Dalam Rangka .... Jurnal Lazuardi, 2(2), 276-292. Retrieved From Http://EjurnalPendidikanbahasaundana.Com/Index.Php/Lazuardijournal/Article/View/11 Matarona, W. (2019). Pendidikan Di Daerah Terpencil. Hidup Katolik. Negara Asean Yang Rentan Terkena Resesi Seperti Singapura. (2020). Retrieved From Cnn Indonesia Website:

Https:/Www.Cnnindonesia.Com/Ekonomi/20200717074537-532-525731/NegaraAsean-Yang-Rentan-Terkena-Resesi-Seperti-Singapura

Nicolas, D. G. (2021). Analisis Penyingkapan Rahasia Di Balik Penderitaan Ayub Di Dalam Kitab Ayub. Syntax Literate: Jurnal Ilmiah Indonesia, 6(3), 1137-1148. Nixon, G., Sabdono, E., And Novalina, M. (2021). Penderitaan Tidak Kasat Mata Di Tengah Pandemi : Analisis Naratif Hakim-Hakim 19 : 1-30 Dalam Perspektif 
Feminis. Kurios: Jurnal Teologi Dan Pendidikan Agama Kristen, 7(1), 70-80.

Nouwen, H. J. M. (1998). Keheningan Sebagai Pusat Hidup Komunitas Yang

Menyuburkan Dalam Komunitas Alternatif (I. Suharyo, Ed.). Yogyakara: Kanisius.

Nouwen, H. J. M. (2008). The Selfless Way Of Christ (R. Isharianto, Ed.). Malang:

Dioma.

Nouwen, H. J. M., Mcneill, D. P., And Morrison, D. A. (1987). Sehati Seperasaan (W.

S. G. Pau, Ed.). Yogyakarta: Kanisius.

Novalina, M. (2020). Spiritualitas Orang Kristen Dalam Menghadirkan Kerajaan Allah

Di Tengah Tantangan Radikalisme. Jurnal Teologi Kontekstual Indonesia, 1(1),

26. Https://Doi.Org/10.46445/Jtki.V1i1.293

Pandor, P. (2014). Aktualisasi Spritualitas Pasionis Di Tengah Orang-Orang Tersalib

Zaman Ini. In E. R. L. Tinambunan And K. Bala (Eds.), Di Mana Letak

Kebahagiaan? (Pp. 81-104). Malang: Stft Widya Sasana Malang 2014.

Pasaribu, R. B. F. (2013). Manusia Dan Penderitaan. In Ilmu Budaya Dasar (Pp. 186214).

Paus Fransiskus. (2015). Misericordiae Vultus Wajah Kerahiman Allah. In Bulla

Pemberitahuan Yubileum Luar Biasa Kerahiman Paus Fransiskus 11 April 2015

(99th Ed.). Jakarta: Depertemen Dokumentasi Dan Penerangan Konferensi

Waligereja Indonesia.

Paus Yohanes Paulus Ii. (1980). Dives In Misericordia Kaya Dalam Kerahiman. In F.X.

Adisusanto Sj And B. H. T. Prasasti (Eds.), Ensiklik (99th Ed.). Jakarta:

Depertemen Dokumentasi Dan Penerangan Konferensi Waligereja Indonesia.

Peter, R. (2020). Pendidikan Agama Kristen Dalam Membangun Wawasan Kebangsaan

Menghadapi Isu Intoleransi Dan Radikalisme. Vox Dei: Jurnal Teologi Dan

Pastoral , 1(2), 89-103. Https://Doi.Org/10.46408/Vxd.V1i2.13

Qodir, Z. (2018). Kaum Muda, Intoleransi, Dan Radikalisme Agama. Jurnal Studi

Pemuda, 5(1), 429. Https://Doi.Org/10.22146/Studipemudaugm.37127

Raharso, A. T. (2019). Reksa Pastoral Gereja Di Era Revolusi Industrri 4.0 (Tinjauan

Hukum Gereja). In C. Valentinus And O. C. Antonius Denny Firmanto Berthold

Anton Pareira (Eds.), Siapakah Manusia; Siapakah Allah Menyingkap Tabir

Manusia Dalam Revolusi Industri Era 4.0. Malang: Stft Widya Sasana Malang.

Rantesalu, M. B. (2020). Penderitaan Dari Sudut Pandang Teologi Injili. Jurnal Ilmiah 
Religiosity Entity Humanity (Jireh), 2(2), 126-135.

Https://Doi.Org/10.37364/Jireh.V2i2.46

Riyanto, A. (2013). Menjadi Mencintai: Berfilsafat Sehari-Hari. Yogyakarta: Kanisius. Riyanto, A. (2018). Relasionalitas Filsafat Fondasi Interpretasi: Aku, Teks, Liyan,

Fenomen. Yogyakarta: Kanisius.

Rouse, J. (2007). Heidegger's Philosophy Of Science. A Companion To Heidegger, 173-189. Https://Doi.Org/10.1002/9780470996492.Ch11

Ryiandi, D., And Ridwan, M. (2021). Bom Bunuh Diri Di Makassar , Ekstremisme Tetap Subur Meski Pandemi. Retrieved April 17, 2021, From Jawa Pos Website: Https://Www.Jawapos.Com/Nasional/28/03/2021/Bom-Bunuh-Diri-Di-MakassarEkstremisme-Tetap-Subur-Meski-Pandemi/

Schutz, A. (2011). Phenomenology And The Social Sciences. In L. E. Embree (Ed.),

Colleted Papers V. Dordrectht: Springer.

Soebagiyo, E. (2020). Humanisme Bagi Sesama - Menyingkap Akar Kekerasan Dalam Relasi Antarmanusia Dan Etika Tanggung Jawab Menurut Emmanuel Levinas. Seri Filsafat Teologi, 30(29), 137-157.

Https://Doi.Org/10.35312/Serifilsafat.V30i29.18

Suchaini, U. (2020). Mewaspadai Bunuh Diri Di Tengah Pandemi. Retrieved From Media Indonesia Website:

Https://Mediaindonesia.Com/Opini/333249/Mewaspadai-Bunuh-Diri-Di-TengahPandemi

Tefbana, A., And Rantung, D. A. (2020). Perspektif Pendidikan Agama Kristen Terhadap Teologi Kebencanaan Dan Peran Gereja Dalam Menghadapi Pendemic Covid 19. Jurnal Luxnos, 6(1), 72-88. Https://Doi.Org/10.47304/J1.V6i1.32

Utomo, K. D. M. (2018). Identitas Diri Dan Spiritualitas Pada Masa Remaja. In A. S. B. Robert Pius Manik, Adi Saptowidodo (Ed.), Pembaharuan Gereja Melalui Katekese Superfisialisme, Aktivisme, Fundamentalisme Dan Spiritualisme Tantangan Katekese Dewasa Ini (Pp. 1-14). Malang: Stft Widya Sasana Malang 2018.

W., B. (2013). Dasar-Dasar Perjuangan Kemerdekaan Papua Barat. Retrieved From Yang Indah Dan Sehat Website:

Https://Bennyw10.Wordpress.Com/2013/08/27/Dasar-Dasar-Perjuangan- 
Kemerdekaan-Papua-Barat-2/

Wilhelmus, O. R. (2013). Hakekat Komunitas Basis Gerejani. Jpak: Jurnal Pendidikan Agama Katolik, 9(5).

Yoni, R. (2020). Memetik Hikmah Jogo Tonggo Dibalik Badai Pandemi Covid-19.

Retrieved From Gatra Com Website:

Https:/Www.Gatra.Com/Detail/News/494736/Kebencanaan/Memetik-Hikmah-

Jogo-Tonggo-Dibalik-Badai-Pandemi-Covid-19 